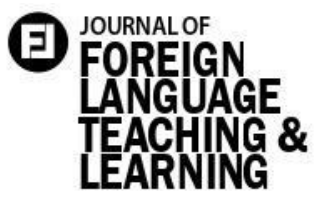

Volume 5, No. 1, 2020

Available online at: journal.umy.ac.id/index.php/FTL/issue/view/610

\author{
Aisha Ganesh Ratnasari \\ received her Bachelor's Degree \\ from English Language \\ Education Department of \\ Universitas Muhammadiyah \\ Yogyakarta. Currently, she is \\ working as a temporary staff at \\ Faculty of Medicines and \\ Health Science of Universitas \\ Muhammadiyah Yogyakarta. \\ Her research interests include \\ teaching media, teaching \\ method, curriculum, and \\ second language acquisition.
}

\section{EFL Students' Challenges in Learning Speaking \\ Skills: A Case Study in Mechanical Engineering \\ Department}

\author{
Aisha Ganesh Ratnasari \\ Universitas Muhammadiyah Yogyakarta \\ aisyahgr17@gmail.com
}

DOI: $\underline{10.18196 / \mathrm{ftl} .5145}$

\begin{abstract}
For particular reasons, English speaking mastery might be important due to its position as one of the most highly used languages. This research aimed to answer the research questions, namely challenges faced by the students in learning speaking skills and strategies implemented by the students to overcome the challenges. Using a case study as the research design, the study involved three participants, who were two Mechanical Engineering Department students and one English teacher in the same department. The data were obtained from interviews and students' speaking grades from classroom presentations. The result showed four challenges, such as lack of vocabulary, nervousness, unsupportive environment, and lack of grammar knowledge. Besides, there were five strategies, such as code-switching, seeing the audiences as the statues, using google translate machines, making a personal approach to the English teacher, and encouraging self.
\end{abstract}

Keywords: speaking skills; challenges in speaking; case study; strategies to overcome challenges in speaking 


\section{Introduction}

English is the most used language by people all over the world. English is also a unifying language when two or more people with different backgrounds meet in a conversation. Harmer (2007) stated that the role of English as lingua franca makes English widely used by many people. Moreover, Abrar et al. (2018) stated that foreign learners had spoken English all over the world. Thus, English will help people to have a conversation and to avoid misunderstanding in giving information.

English in Indonesia is a foreign language where English is not the main language, but the students still can learn it, and most schools oblige students to learn it. English as a Foreign Language (EFL) students still faced some challenges, either spoken or written in learning English. As mentioned by Abdulrahman (2013), every student has challenges in learning English. Jin (2014) added that English helps enhance students' capabilities, especially in students' proficiency.

Language skills, the way how the students use the language, becomes the focus of learning English. There are two types, such as receptive skills and productive skills. Masduqi (2016) explained about receptive skills and productive skills as follows. Receptive skills, listening, and reading skills, is the condition where the students receive the information from the teacher. Meanwhile, productive skills, speaking, and writing skills is the condition where the students produce the language.

Speaking is the main skill compared to other skills, such as writing, reading, and listening. Speaking is the main of the language because it shows people's language measurement (Shteiwi \& Hamuda, 2016). Besides, speaking is important for the students to master because it can make the students can communicate easily (Nazara, 2011).

The researcher observed that Mechanical Engineering Department students, one of EFL students', faced some challenges in speaking in English. First, the students felt that they were lack vocabulary. Second, the students felt confused when they wanted to speak when the teacher asked them to speak. Third, the students were lack exposure in English because English only taught in one week. Thus, the Mechanical Engineering Department students felt that speaking in English was quite challenging.

The previous study had discussed challenges in speaking skills with its strategies from teacher perspectives. According to Al-Esaifer and AlShareef 


\section{Journal of Foreign Language Teaching and Learning \\ VOLUME 5, NO. 1, 2020}

(2018), the common challenges of speaking faced by the students are mother tongue and linguistic, for example, vocabulary. Similarly, this research only discussed the strategies to overcome the challenges from teacher perspectives. However, none of the previous studies studied both challenges and strategies from students' perspectives.

Based on the explanations above, the researcher is interested in investigating the challenges faced by Mechanical Engineering Department students in the English classroom. It aims to find out about the challenges they faced. Also, the researcher is interested in investigating the strategies implemented by the Mechanical Engineering Department students in the English classroom. It aims to know the things they do to overcome the challenges in the English classroom. By reading this research, future researchers and other parties will know the suitable methodology for overcoming the problems.

\section{Literature Review}

\section{Type of Language Skills}

There are two types of language skills, such as receptive skills and productive skills. Masduqi (2016) stated that receptive skills are the situation when the students receive information from the teacher. There are two skills included in receptive skills, such as listening and reading skills.

Meanwhile, Masduqi (2016) also stated that productive skills are the skills when the students produce the language. There are two skills in productive skills, such as speaking and writing skills.

\section{Speaking Skills}

Speaking skills are one out of four skills in language skills. Speaking is the situation when people express their minds into a language. Febriyanti (2011) stated that speaking is the condition when people transfer their ideas into verbal and nonverbal communication. Nowadays, the students need to master speaking skills in English language learning because, by speaking, they will know someone's language measurement (Nazara, 2011). Further, Nazara (2011) also stated that speaking mastery is important due to the position of English as the universal language.

\section{Challenges of Speaking English for EFL Students}

In the environment, speaking is a tool for communication, and people will see students' proficiency in speaking in English (Ihsan, Muslem \& Aziz, 2018). The students, especially EFL students', can not 


\section{Journal of Foreign Language Teaching and Learning \\ VOLUME 5, NO. 1, 2020}

learn it fast. It should be step by step and need to be developed (Ihsan et al., 2018). There are some challenges faced by the students, such as lack of vocabulary, fear of mistake and shyness, anxiety, lack of confidence, and lack of motivation.

Lack of vocabulary. This issue is the first challenge faced by the students in learning speaking skills. Dewi and Jimmi (2018) stated that lack of vocabulary is the condition when the students cannot build the sentence because of limitation words. Similarly, vocabulary is an important part of learning English. Dewi and Jimmi (2018) supported by stating that the range score of vocabulary was 48 , and the range score of speaking was 23. Further, Dewi and Jimmi (2018) stated that the students who lack the vocabulary will have an impact on themselves when they want to have interaction and would have less confidence.

Fear of mistake and shyness. These psychological factors are the emotional feeling of the students when they want to speak in English (Juhana, 2018). Juhana (2018) stated that the students would forget what they want to say because of shyness, students' fear of whether they make a mistake or not when speaking in English, and also they are worried about being laughed by their friends. Juhana (2018) mentioned that $37 \%$ of the students mostly chose fear of mistake, and $26 \%$ of the students chose shyness. Moreover, these psychological factors have influenced students' speaking performance. Further, teachers can make a personal approach and create a better learning atmosphere in the classroom.

Lack of confidence. This psychological factor is a student feeling that occurs when the students realize that their speaking partners do not get their points when speaking in English (Juhana, 2018). Similarly, the students' feel a lack of confidence because they feel their English is not good, and they keep silent. Additionally, $13 \%$ of the students chose a lack of confidence as one of the challenges in speaking English (Juhana, 2018). To make the students' have high confidence, the teachers should give positive encouragement to the students.

Lack of motivation. In language learning, especially when speaking in English, motivation is vital for students. Jin (2014) stated that motivation is important to make students successful in language learning. Juhana (2018) added that $6 \%$ of the students chose a lack of confidence because they do not have motivation when they see their teacher's way of teaching. 
Similarly, the teacher should show their enthusiasm by showing their activeness using English to communicate and during their teaching process (Juhana, 2018).

\section{Strategies of Speaking English of EFL}

\section{Students}

The problem faced by EFL students is that they understand what other people talk about, but they have less confidence when speaking in English. In this case, speaking is not merely about the way how people communicate but also how they try to share the information (Abrar et al., 2018).

There are some strategies used by EFL students' in overcoming challenges such as self-assessments, metacognitive strategies, cognitive strategies, social strategies, interpersonal strategies, and communicative-experiential strategies.

Self-assessment. In this strategy, the teacher asks the students to do selfassessments. The students state their strengths and weaknesses in speaking in English. Mahdi (2015) stated that this strategy could have a good impact on the teacher because they could know the capabilities of every student. Similarly, the teacher will know the capabilities through the questionnaire the teacher distributed.
Additionally, the students can write their strength and their weaknesses in speaking in English (Mahdi, 2015).

Metacognitive strategies. The students implement this strategy during the learning process. The students applied several ways, such as setting the purpose of speaking in English, self-monitor, and evaluation for their academic achievement and set the material to be discussed (Heryanti \& Hazairin, 2017). Similarly, the total participants in their research were 6 participants. 6 participants chose to set the purpose of speaking in English. Two participants chose self-monitor and selfevaluation also, 4 participants chose to set the discussed material (Heryanti \& Hazairin, 2017). Thus, it can help the students to enhance their speaking performance in the classroom.

Cognitive strategies. In this strategy, 5 students chose to translate, and 6 students chose repetition, also guessing the meaning of vocabulary as their strategies to overcome the problem (Heryanti \& Hazairin, 2017). Additionally, Heryanti and Hazairin (2017) also stated that students chose to guess the meaning, and 5 students make some clues of vocabularies as their strategies to overcome the problem. By doing those strategies, the 
students believe they can enhance their speaking performance later on.

Social strategies. This strategy aims to make the students an active learner in learning speaking skills. The students applied several ways in this strategy, such as 6 students chose cooperation ways, 4 students questioned for clarification, and 2 students chose self-talk (Heryanti \& Hazairin, 2017). Additionally, the students use questioning for clarification and self-talk in order to prepare themselves in some instances, such as speaking in public, speech, or presentation (Heryanti \& Hazairin, 2017).

Interpersonal strategies. In this strategy, the students need to rehearse for their speaking performance in the classroom. Heryanti and Hazairin (2017) stated several ways in this strategy, such as 6 students ask the other people to give some suggestions, 5 students chose to practice and rehearsal also 6 students try to speak up with other people. Furthermore, students can overcome their challenges in speaking in English.

\section{Communicative-experiential}

strategies. In this strategy, 6 students can make an effective sentence by finding the synonym. The students need support from the teacher to overcome their challenges in speaking in English (Heryanti \& Hazairin, 2017). Additionally, 4 students will easy to speak up by guessing teachers' body language (Heryanti \& Hazairin, 2017).

\section{Previous Studies}

The first study was conducted by Abrar et al. (2018), which aimed to document Indonesian EFL students' teachers' experiences in speaking English. This study used a qualitative phenomenological study to gather the data. In this research, the participant was 8 people. The results of this research were language barriers such as pronunciation, grammar, vocabulary and fluency, psychological factors such as anxiety, attitude and lack of motivation, learning environment such as lectures, peers, and topic of speaking, and practicing the language such as self-practice, practice with tutors also practice uses media and technology.

The second study was conducted by Nazara (2011) that aimed to investigate the perceptions of students of English speaking skill development. To gather the data, the researcher used mix methods such as qualitative study using interviews and a quantitative study using a questionnaire. 
The questionnaire contained 16 statements with 40 respondents.

Meanwhile, the interview lasted for 20 - 25 minutes, with five respondents administered in a voluntary system. This interview aimed to re-check participants' points of view rather than make generalizations. The result was showing that $45 \%$ of participants knew their speaking level was high, while $55 \%$ of participants were not. Thus, the participants wanted to speak in English, and for that matter, speaking mastery was important for them.

The third study was conducted by Juhana (2018), which aimed to find out psychological factors that hindered students from speaking and the causes of the factor as well as possible solutions to overcome the factors. This study used three techniques of gathering data, such as observations, questionnaires, and interviews. The result

EFL teaching and learning of Mechanical Engineering Department students in learning speaking skills in English classroom. showed that there were five psychological factors in speaking in English, such as fear of mistake (37\%), shyness (26\%), anxiety (18\%), lack of confidence (13\%), and lack of motivation (6\%). Based on this research, the solution depended on how the teacher could motivate the students and asked them to participate actively in the learning process.

\section{Conceptual Framework}

The previous research explained about challenges and strategies from students' point of view. In this research, the researcher would like to explore the other challenges and strategies from students' points of view about speaking skills that might appear. Moreover, the researcher also used the previous research as references to enrich the data in this research. Research's conceptual framework is in the figure below.

Challenges in speaking in English among Mechanical Engineering Department students in English classroom.

Strategies to overcome the challenges in speaking in English among Mechanical Engineering Department students in English classroom. 
Figure 1. Conceptual Framework

\section{Methodology}

\section{Research Design}

The researcher used a qualitative data approach as the research design to collect the data. The qualitative data approach explored information from participants, and the result was in the form of words (Creswell, 2012). The researcher decided to use qualitative because she wanted to get in-depth data based on the phenomenon.

To deepen the data, the researcher used a case study to get the exact data about the phenomenon based on real-life context. Yin revealed that in order to investigate the phenomenon, a case study was used (as cited in Merriam, 1998). Additionally, the researcher used a case study because of its two characteristics. First, it bounded by time and place as well as what mentioned by Creswell (2012) that case study was specific to the case. Second, a case study used multiple data collection. In this research, the researcher used to interview and students' speaking grades in order to gather the data. In the case study, there was no limitation in collecting the data (Creswell, 2012).

The interview was for the English teacher and the students. The English teacher confirmed students' speaking performance in the classroom. Besides, the researcher searched for information about the speaking class atmosphere in an interview with the experienced students. Other than that, the researcher also asked the time of the speaking class to achieve specific information.

\section{Research Setting}

Mechanical Engineering Department, specifically at one of Private University in Yogyakarta, was the setting of this research. The goal of the English subject was English for Specific Purposes (ESP), where the English teacher only taught about English terms related to the department.

Meanwhile, the stakeholders of the department did not want to know whether the students were capable or not. In the end, the students faced some challenges in learning English, especially in speaking in English.

There were two reasons why the researcher took this place. First, the students had learned English in two semesters, such as a third and fourth semester. The material were different between both semesters. In semester 3, the English teacher taught about reading and listening skills, but in semester 4, the English teacher taught about writing 


\section{Journal of Foreign Language Teaching and Learning \\ VOLUME 5, NO. 1, 2020}

skills and presentation. In this department, the students did not learn about speaking skills. Speaking skills used by the teacher in order to make the learning atmosphere became interactive. Additionally, speaking used specifically in a presentation in semester 4. Further, the students had some challenges in speaking in English.

To assess students' speaking performance, the English teacher had made a scoring rubric in several categories. There were organizations, content, and presentation, which each of them had different worth. The total worth of categories was 100 which had divided into 5 and made it in the form of a percentage. Additionally, the highest score for the presentation was 20\%, and the English teacher would give it when the students' delivered the presentation.

Second, there was a program named English Study Club (ESC) held by the organization, Himpunan Mahasiswa Mesin (HMM), in the Mechanical Engineering Department. The researcher had experienced teaching English in the program for around one year. This program aimed to make the students became easy in learning English, especially speaking in English. The duration for every meeting was 90 minutes with the material about TOEFL, grammar, and speaking skills. By seeing the experience of the researcher and also the material, the researcher finally chose this department as the setting of this research. Additionally, it could make the researcher easier to conduct this research and enrich the explanation when collecting the data.

\section{Research Participants}

This research used non-probability samples. Cohen, Manion and Morrison (2011) stated that this kind of sample only represents itself from a wider population. Similarly, the researcher used purposive sampling, which took the sample from participants' points of view in order to look for the participants based on charateristics.

In this research, three participants used the pseudonym, such as Olaf, Elsa, and Anna, to keep privacy. Olaf and Elsa, participant 1 and participant 2, were the students of the Mechanical Engineering Department. They were selected based on the criteria and based on the researcher's experience when teaching English in English Study Club (ESC). Additionally, Anna, participant 3, was an English teacher in the same department. Anna was selected based on criteria and based on her experience when teaching English for two years, from 


\section{Journal of Foreign Language Teaching and Learning \\ VOLUME 5, NO. 1, 2020}

2016 and 2017 in the same department.

Further, Anna's statement added to enrich the data of this research.

As mentioned above, there were three criteria to select the participants. First, to limit the scope of this research, the participants should be the students of the Mechanical Engineering Department of that University. Second, the participants had been enrolled in an English class and had passed the class. By doing so, the researcher could easy to interview the participants because they had experienced to join the class. Third, the participants should articulate. Further, the researcher could know the problem with the phenomenon in a real context.

The researcher also had the criteria for the teacher since the participants were not only the students. On the other side, the criteria were that only the teacher should be an English teacher in the Mechanical Engineering Department of that University. Additionally, the researcher also asked students' speaking grades that assessed through classroom presentations from an English teacher. Furthermore, the data of this research had gotten from two points of view which were the students and the English teacher.

\section{Data Collection Technique}

One of the characteristics of the case study was multiple data collection. The researcher used the interview and students' speaking grades to seek the data related to the topic. The interview happened when there was a hot topic related to the real-life context (Cohen et al., 2011). Also, the standardized open-ended interview was used in this research because it contains the research step (Cohen et al., 2011). Similarly, the researcher used open-ended items in order to ask deeper into the participants related to the research topic.

\section{Data Collection Procedure}

The researcher had done several procedures. First, the researcher made an interview guideline to collect the data. The second step was to select the participants based on the criteria. Then, the researcher contacted the selected participants and managed the time and place also their availability to interview.

During the interview, the researcher used Bahasa Indonesia in order to avoid misunderstanding of information. On the other side, Bahasa Indonesia is also the participants' first language. Besides, the researcher used a cellphone to record the conversation for 25 minutes for each 
participant. By doing so, the researcher could get comprehensive data in this research. Further, the research did follow up question to two participants, Olaf and Elsa, for 25 minutes. The researcher asked about the strategies directly they implemented directly to overcome the challenges. Therefore, the data more specific and comprehensive.

\section{Data Analysis}

There were several ways to analyze data, such as transcribing, member checking, coding, and content analysis.

Transcribing. It is the process of changing the data from oral into a written language (Cohen et al., 2011). In this step, the name had been changed into pseudonym names by the researcher in order to keep the privacy.

\section{Member checking. Member}

checking aimed to re-check the data, whether right or not. The participants could add some missed information if any, and they are allowed to give the clarifications toward the data. Also, the participants had been gotten the data from the researcher through email. Furthermore, all participants approved the data in this research.
Coding. In this step, the researcher used a label that contains an information (Cohen et al., 2011). Similarly, there were four steps of coding, such as open coding, analytic coding, axial coding, and selective coding.

Open coding. It was the first step in coding, in which the researcher made a column in order to arrange the data, including translated statements, themes, categories, time, and place to conduct the interview. Strauss and Corbin indicated that open coding was generated and defined as the phenomenon on the data (as cited Cohen et al., 2011). Moreover, the researcher gave the data a title or name based on researchers' criteria after grouped into several categories (Cohen et al., 2011).

Analytic coding. The second step after open coding was analytic coding. In this step, the data were more specific because there was more explanation about the data (Cohen et al., 2011). In short, the researcher gave a code after participants' explanation with P1.1.1 where P1 means first participant, 1 means first research question, and the last 1 means the number of participants' statements for every research question.

Axial coding. It was the third part of coding. The researcher put the data into 
the same categories in order to get the finding of this research. Further, the researcher connected the same data into one group (Cohen et al., 2011).

Selective coding. The last part after all steps of coding was selective coding. In this step, the researcher connected the data into several categories (Cohen et al., 2011). To get the finding of this research, the researcher made a brief explanation in selective coding.

Content Analysis. It was the last step in coding, where the researcher made the summarize of the research (Cohen et al., 2011). Krippendorff defined content analysis as the situation when the researcher made a meaningful summarize of the research's data (as cited in Cohen et al., 2011).

\section{Findings}

In this research, the researcher interviewed three participants, such as two Mechanical Engineering Department students and one English teacher in the same department. The researcher had changed the name into pseudonym names to keep the privacy of the participants. The students, Olaf, as participant 1 and Elsa, as participant 2, while the English teacher,
Anna, as participant 3. Furthermore, the researcher also used students' speaking grades to compare with students speaking performance in the classroom.

There were two main findings in this research - first, the challenges faced by EFL students in learning speaking skills. Second, the strategies implemented by EFL students to overcome the challenges. These statements were according to the students, but the English teacher supported it by seeing their performances in the classroom.

Olaf, as participant 1 , was the sophomore of the Mechanical Engineering Department. He had a different English background when he was in school and University. In University, he had to participate actively in the classroom, and he had to ask a question when in a classroom presentation. Meanwhile, in school, he thought that English is hard because he did not like English. On the other side, he thought that the English teacher was great. Based on the English teacher's data on students' speaking performance, his speaking grade was $13 \%$ out of $20 \%$ in a classroom presentation. Additionally, he still found some challenges in speaking in English.

There are two challenges faced by Olaf in speaking in English. First, lack of 


\section{Journal of Foreign Language Teaching and Learning \\ VOLUME 5, NO. 1, 2020}

vocabulary. $\mathrm{He}$ considered that the frequency of reading an English book could be the cause of why these challenges occurred. "I seldom read an English book, so I feel my vocabulary is limited" (P1.1.1). Anna, the English teacher, considered the same way. "His vocabularies is still limited" (P3.1.4).

Moreover, when Olaf delivered the presentation, he still brought the notes. Additionally, Anna asserted the same way "His English has not really fluent but he was confident and diligent. So he can follow the material, but when it comes to presentation emm.. he still needs notes"(P3.1.4).

The second challenge was nervousness. Nervousness happened when Olaf had to deliver a presentation in front of the public, his English teacher, and his friends in the classroom. As mentioned by Olaf, "because I did not get used to speak in front of the classroom using English, so I got nervous" (P1.1.2). Besides, he also asserted that he was nervous when asked to come forward in front of the classroom and when he wanted to ask a question, as mentioned by Olaf, "When I want to come forward in the classroom. I got nervous because I do not get used to speak in the public"(P1.1.2), and "I got nervous not only when I want to come forward but when I want to ask"(P1.1.2).
Additionally, he believed that this challenge commonly happened to everyone.

There were two strategies implemented by Olaf, such as codeswitching and seeing his friends as statues. First, Olaf did code-switching to overcome his vocabularies. He used code-switching to make the other people, his English teacher, and his friends understood what he would like to say. "I mix the language with Bahasa Indonesia"(P1.2.1). He added that his English teacher understood what he said.

Second, seeing Olaf's friends as statues, he was trying to calm himself and then seeing his friends as statues. He also made it into an informal situation so that he believed that it could reduce his nervousness. Also, it was in line with his statements, "stay calm and see the audience as statues" (P1.2.2) and "I do not make it serious so it can reduce my nervousness"(P1.2.2). Further, he believed that it could reduce his nervousness when speaking in English.

Elsa, as participant 2, was a sophomore in Mechanical Engineering Department. Elsa's English background was quite different from Olaf. She had good ability in English since she was in Senior High School. It happened because her school status already Rintisan Sekolah Bertaraf 


\section{Journal of Foreign Language Teaching and Learning \\ VOLUME 5, NO. 1, 2020}

Internasional (RSBI) and students' worksheet was bilingual. Besides, her teachers also used English when they wanted to communicate with the students. In conclusion, Elsa's environment supported her to speak using English, and it had a positive impact on her English ability.

Elsa's speaking grade was $16 \%$ out of $20 \%$ based on teacher's data on students' speaking performance. Unfortunately, she still found some challenges in speaking in English, along she studied at the university. The first is the unsupportive environment in the classroom. She argued that an environment had an impact on her. She mentioned, "I just do what my friends do because if I want to be the active student, I think they would not like it.. so I follow them"(P2.1.1). Similarly, she implemented that the environment had an impact on her ability to speak in English.

The second challenge was "Vocabulary"(P2.1.2). She needed guidance from the teacher because she believed that her vocabulary did not become rich. She confirmed that "the facilitator had not improved students' ability”(P2.1.2). Additionally, there was the reason why she needed many improvements in vocabulary.

The third is the grammar. Elsa needed a follow up from the teacher because when she wanted to deliver a presentation or writing, the teacher only corrected it. Similar to what she confirmed, "when I want to do a presentation or writing, the teacher only corrected, and there was no follow up from the teacher"(P2.1.3). Besides, English teacher, Anna also confirmed that every student, especially Elsa, wanted to speak, they often see whether grammar was right or not. Further, this often happened to the students, as Anna mentioned: "That is the problem because even the other people before they speak they see the grammar first"(P3.1.1).

To overcome the challenges, Elsa had three strategies, such as encourage herself, the use of Google translate machine and personal approach to the English teacher. First, she was encouraging herself as well as she stated: "Encourage myself in the classroom"(P2.2.1). She believed that when she encouraged herself, she could one step ahead from her friends. Further, its way could overcome the challenges.

Second, Elsa used a Google translates machine. Elsa used Google translate machine to search the unknown vocabularies. She revealed that "Browsing on the internet. google translate"(P2.2.2). When Elsa and her friends did not know the meaning of vocabularies, she browsed the 


\section{Journal of Foreign Language Teaching and Learning \\ VOLUME 5, NO. 1, 2020}

meaning used Google translate machine. Further, she confirmed, "for example, when my friend and I already prepared the material for the presentation, and we do not know the meaning. So we are just browsing in the classroom"(P2.2.2).

Third, Elsa made personal approach to the English teacher. She asked whether her grammar was right or not. Moreover, she confirmed, "Approach to the teacher whether grammar is correct or not"(P2.2.3). Further, the English teacher gave her feedback to the students.

\section{Discussions}

There were two main topics such as challenges faced by the students in speaking in English and strategies implemented by the students to overcome the challenges. In those main topics, there were similarities and differences between Olaf and Elsa. Lack of vocabulary was the similarity of challenges faced by both participants, Olaf and Elsa, while there was no similarity between the strategies implemented by both participants. Also, the result of this research was according to the participants' experiences in speaking English. Further, scholar arguments would support their explanation.

\section{Challenges in speaking in English.} It was the first main topic in this research. In this topic, there was a similarity between Olaf and Elsa, and it was a lack of vocabulary. Olaf and Elsa still faced other challenges such as nervousness faced by Olaf and Elsa faced unsupportive environment also lack of grammar knowledge as the other challenges. The detail was below.

Lack of vocabulary. The first challenge faced by the students was lack of vocabulary. Both participants, Olaf and Elsa, faced these challenges in learning speaking in English. Olaf and Elsa had different causes, even though both of them faced the same strategies. Olaf thought he was lack of vocabulary because he seldom read a book. That is why he felt his vocabulary was limited.

Meanwhile, Elsa felt she had a limited vocabulary because there were no improvements from the facilitator. Moreover, vocabulary had an important role in learning a foreign language (Khan et al., 2018). Similarly, when the students had a rich vocabulary, it could help them in communication.

Nervousness. The second challenge was nervousness. In these challenges, only Olaf faced nervousness when he was speaking in English. It happened because he did not use to speak in front of the public. In the classroom, nervousness also 


\section{Journal of Foreign Language Teaching and Learning \\ VOLUME 5, NO. 1, 2020}

happened when his English teacher asked him to speak or asked a question when there was a presentation.

Further, he realized that this problem commonly happened to everyone. Nervousness naturally happened to everyone when they had to speak (Moghaddam \& Ghafournia, 2019). Additionally, Nervousness could have an impact on the students' language learning and students' oral communication.

Unsupportive environment. This third challenge faced by Elsa became a problem because Elsa felt when she wanted to be an active student, her friends would not like it. She made much effort into learning English. Also, an unsupportive environment would have an impact on the students. Further, one of the impacts was that the students would feel demotivated to learn and lost their creativity in language learning (Alharbi, 2015).

Lack of grammar knowledge. The fourth challenge faced by the students was lack of grammar knowledge. Grammar was a common problem when the students wanted to speak using English. The students tend to see the use of grammar first before they speak. Elsa also felt the same way before she spoke in front of the classroom. She tended to see her grammar before she spoke, and it had affected her ability when she had to do a presentation and writing.

Moreover, her English teacher did not follow up on her grammar, both speaking and writing. Further, grammar was a big concern when the students speaking in English because they were fearful of a mistake they would make during speaking (Abrar et al., 2018). Similarly, the students still enhanced themselves to speak using English.

Strategies implemented by EFL students. This part explained the strategies used by two participants to overcome the challenges. Both participants, Olaf and Elsa, had different strategies in this case. Olaf implemented code-switching and seeing his friends as statues but Elsa implemented encouraging self, using Google translate machine and personal approach to her English teacher. The detail was below.

Code-switching. It is the first strategy implemented by Olaf to cope with his challenges. Besides, his English teacher also understood what he said in the classroom. Additionally, code-switching was the situation when the students mix the language into Bahasa Indonesia in communication. By doing code-switching, it could make the speaker ease in 
communication with other people (Hartmann, Choudhury \& Bali, 2018).

\section{Seeing the audiences as the statues.}

The second strategy implemented by Olaf to overcome the challenges was nervousness. As he mentioned, he needed to make himself relax when he asked to come in front of the classroom. Also, he saw his friends as the statues, so he believed his nervousness reduced. Unfortunately, there was no support from the research related to challenges in speaking in English.

\section{Using Google translate machine. It} was the first strategy implemented by Elsa to cope with her challenges. Elsa used Google translate machine as her first strategy to overcome her challenges. She used it to search an unknown vocabulary, and she believed that Google translates machine could enhance her and the other students' capabilities. Additionally, most of the students used Google translate machine to enhance their capabilities in English language learning (Bahri \& Mahadi, 2016).

\section{Making a personal approach to the}

English teacher. It was the second strategy implemented by Elsa. To overcome her challenges in grammar knowledge, she made personal approach to her English teacher. She needed feedback from the teacher, whether her grammar right or not.
Additionally, her English teacher gave feedback to Elsa. To sum up, Heryanti and Hazairin (2017) believed that when the students asked a suggestion from other people, it could enhance their performance in the classroom.

Encouraging self. Elsa was encouraging herself in the classroom as the third strategy to overcome the challenges. Elsa believed that she could one step ahead in front of her friends. Additionally, selftalk, as one of the learning strategies were used by the students to prepare themselves in the classroom (Heryanti \& Hazairin, 2017).

Based on the result of this study, several aspects affect students' performance in the classroom. There were students' English background and students' grades. Further, the students who had high grades could not guarantee that she/he did not have any challenges in learning English, especially speaking. Additionally, it needed guidance from the teacher to support students' performance.

\section{Conclusion and Implications}

Speaking is the most difficult skill because the students need to share their ideas in oral so that it needs much practice. 


\section{Journal of Foreign Language Teaching and Learning \\ VOLUME 5, NO. 1, 2020}

The teacher can use visuals to make the learning atmosphere interactive. Additionally, the teacher can give oral feedback to students' speaking performance. The implementation of English in Indonesia was English as a foreign language where the students still learn it, but it was not as a main language. One of the EFL students, Mechanical Engineering Department, still faced some challenges in learning English, especially in learning speaking English. In short, there are three participants, such as two students and one English teacher. The name had been changed into pseudonym names into Olaf, Elsa, and Anna in order to keep the privacy of the participants. However, this research used a case study because of this research based on a phenomenon that happened in real-life. Other than that, the researcher interviewed the participants and used students speaking grades to make a comparison with their performances in the classroom.

Fortunately, there are four findings of challenges in learning speaking in English, such as lack of vocabulary, nervousness, unsupportive environment, and lack of grammar knowledge. Moreover, there are five findings of strategies such as using Google translate machine, codeswitching, seeing the audiences as the statues, making a personal approach to the
English teacher, and encouraging self. In short, the high grade of students does not guarantee that the students do not have any challenges. The environment and English background of the students can affect students' performance in language learning, especially speaking. Additionally, future researchers can observe students' performance directly in the classroom. Further, the future researcher also can broaden the limitation of the study in order to get various data.

\section{References}

Abdulrahman, H. (2013). What are the difficulties and problems in learning English? Retrieved from: https://www.bayt.com/en/specialties/q /57074/what-are-the-difficulties-andproblems-in-learning-english/

Abrar, M., Mukminin, A., Habibi, A., Asyrafi, F., Makmur, M., \& Marzulina, L. (2018). "If our English isn't a language, what is it?"Indonesian EFL student teachers' challenges in speaking English. The Qualitative Report, 23(1), 129-145.

Al-Esaifer, F. S. A., \& Alshareef, H. M. A. (2018). Speaking challenges that encounter 2 nd and $3 r d$ year EFL university students. Premise: Journal of English Education, 7(1), 49-56.

Alharbi, A. H. (2015). Improving students' english speaking proficiency in saudi public schools. International Journal of Instruction, 8(1), 105-116.

Bahri, H., \& Mahadi, T. S. (2016). Google translate as a supplementary tool for learning malay: A case study at 
universiti sains Malaysia. Advances in

Language and Literary Studies, 7(3), 161167.

Cohen, L., Manion, L., \& Morrison, K. (2011). Research methods in education (7th ed.) London: Routledge.

Creswell, J. W. (2012). Education research: Planning, conducting, and evaluating quantitative and qualitative research (4th ed.). Boston: Pearson.

Dewi, N., \& Jimmi, J. (2018). The correlation between vocabulary mastery and self-esteem on students' speaking skill. Wanastra, 10(1), 78-83.

Febriyanti, E. R. (2011). Teaching speaking of English as a foreign language: Problems and solutions. Jurnal Bahasa, Sastra, dan Pembelajarannya, 1(2), 133. 146.

Harmer, J. (2007). The practice of English language teaching. England: Pearson Education.

Hartmann, S., Choudhury, M., \& Bali, K. (2018). An integrated representation of linguistic and social functions of codeswitching. In Proceedings of the Eleventh International Conference on Language Resources and Evaluation (LREC-2018).

Heryanti, R., \& Hazairin, I. N. (2017). Learning strategies used by the fifthsemester students to increase their speaking proficiency at english study program in jambi university. JambiEnglish Language Teaching Jurnal, 2(1), 27-36.

Ihsan, M., Muslem, A., \& Aziz, Z. A. (2018). Using the participation point system in teaching speaking skills. English Education Journal, 9(2), 176-191. Jin, M. (2014). A case study of non-English major college students' motivation in
English language learning. Open Journal of Modern Linguistics, 4(2), 252-259.

Juhana. (2018). Psychological factors that hinder students from speaking in English class (A case study in a senior high school in South Tangerang, Banten, Indonesia). Journal of Education and Practice, 3(12), 100-110.

Khan, R. M., Radzuan, N. R., Shahbaz, M., Ibrahim, A. H., \& Mustafa, G. (2018). The role of vocabulary knowledge in speaking development of Saudi EFL learners. International Peer Reviewed Journal, 9(1), 406-418.

Mahdi, D. A. (2015). Motivating reluctant EFL students to talk in class: Strategies and tactics. Theory and Practice in Language Studies, 5(8), 1703-1709.

Masduqi, H. (2016). Integrating receptive skills and productive skills into a reading lesson. Proceeding the 2 nd International Conference on Teacher Training and Education, 2(1), 507-511.

Merriam, S.B. (1998). Qualitative research and case study applications in education. San Francisco: Jossey-Bass Publishers.

Moghaddam, M. S., \& Ghafournia, N. (2019). Elaboration on foreign language anxiety in L2 speaking: A study of Iranian EFL learners. International Journal of Foreign Language Teaching $\mathbb{E}$ Research, 7(26), 137-156.

Nazara, S. (2011). Students' perception on EFL speaking skill development. Journal of English Teaching, 1(1), 28-43.

Shteiwi, A. A., \& Hamuda, M. A. (2016). Oral communication problems encountering english major students: Causes \& remedies. International Journal of Social Science and Humanities Research, 4(2), 19-26. 